INTERNATIONAL JOURNAL OF RESEARCHES IN BIOSCIENCES, AGRICULTURE AND TECHNOLOGY (C) VISHWASHANTI MULTIPURPOSE SOCIETY (Global Peace Multipurpose Society) R. No. MH-659/13(N)

www.vmsindia.org

\title{
STUDIES ON FUNGI ASSOCIATED WITH SPOILAGE OF FRUITS, GRAINS AND VEGETABLES OF SELECTED PLANTS
}

\author{
R. S. Dhande ${ }^{1}$, S. N. Patole ${ }^{2}$ and V. B. Bhagat ${ }^{3}$ \\ ${ }_{1,2}$ Department of Botany, Shri Shivaji Arts, Commerce and Science College, Akot (M.S.) \\ ${ }^{3}$ Department of Zoology, Shri Shivaji Arts, Commerce and Science College, Akot (M.S.) \\ ravi_dhande2005@yahoo.co.in
}

\begin{abstract}
:
A study was carried out to find out fungi associated with the spoilage of different fruits, grains and vegetables during their post harvest period. A total of twelve strains of fungi were isolated and identified as Botrytis cinerea, Uncinula Spp., Colletotricum Spp., Fusarium Spp., Aspergillus niger, Aspergillus flavus, Rhizopus Spp., Diplodia Spp., Tilletia Spp., Phytophthora infestans, Alternaria alternata and S. cerevisiae. These fungi are responsible for causing rottening of the fruits and gross loss of productivity.
\end{abstract}

Key words: Fungi, Spoilage, Fruits, Grains, Vegetables

\section{Introduction}

Fruits, grains and vegetables are of great economic importance. These are the dietary sources of carbohydrates, proteins, vitamins and minerals. Some of the fruits also have medicinal importance. Wide range of microorganisms affects the growth and quality of the agricultural products. Spoilage can also be referred to as rot or decay that leads to deterioration in quality. Spoilt fruits are characterized by excess softening, mycelial growth, unpleasant odour and shrinkage (Franzier and Westhoff, 1991). The occurrence of spoilage in fruits by microorganisms depends on the types of organisms present and whether the fruit under its existing condition of storage can support the growth of any or all of them. Only certain species out of all the organisms present in a fruit will be able to thrive well and spoil it. Spoilage by microorganisms may be influenced by some qualities such as water content, $\mathrm{pH}$ value, temperature, texture and nutrient composition of the fruit (Lloyd, 1993). In comparison to other microbes, Fungi singly cause more plant diseases than any other group of plant pest with over 8,000 species shown to cause disease. In this paper, the different fruits of various plants, grains and vegetables infected by pathogenic fungi are studied and the causal organisms are identified

\section{Materials and Method}

The infected ripe fruits, grains and vegetables such as Strawberry, Pomegranate, Grapes, Banana, Apple, Watermelon, Papaya, Custard apple, Beet root, Wheat grains, Potato tubers, Sorghum grains, Tomato fruit and Onion bulb were collected from different fruit stores, grain stores and vegetable stores of Akot, India. The fruits were collected into a sterile polythene bag and brought to the laboratory for the study. Potato Dextrose Agar (PDA) (Downes F. P. and
Ito K., (Eds.), 2001) used in this study was prepared for plating. Bacterial contamination was inhibited by aseptically adding $2 \mathrm{ml}$ of streptomycin antibiotic to $1000 \mathrm{ml}$ of the sterile medium prior to pouring into sterile petriplates. Surface sterilization of the infected portion of the fruits was done using $70 \%$ alcohol, the fruits were then rinsed with sterile distilled water. The infected grains were also surface sterilized. Small portions of the infected parts of the fruits and grains were aseptically inoculated on sterilized PDA and incubated at $26 \pm 1^{\circ} \mathrm{C}$ for 72 to 96 hours. The colonies on the plates were observed and subcultured until pure cultures of isolates were obtained. The pure cultures were maintained on agar slants which were kept as stock cultures under refrigeration $\left(4^{\circ} \mathrm{C}\right)$ for subsequent use. The isolates were characterized based on their colonial and cellular morphology. The colonial morphology of the isolates was observed and characteristics such as color of mycelia and spores, shape and surface texture were noted. The isolates were then observed under light microscope for their cellular morphology (hyphal nature and disposition of mature fruiting structures) by using wet mounting method. The fungal isolates were compared with those of fungi in a compendium of pathogenic fungus by Barnnet and Hunter (1972).

\section{Results and Discussion}

A total of twelve strains of fungi were isolated and identified during the study as Botrytis cinerea, Uncinula necator, Colletotricum musae, Fusarium oxysporum, Aspergillus niger, Aspergillus flavus, Rhizopus stolonifer, Diplodia natalensis, Tilletia indica, Phytophthora infestans, Alternaria alternata and S. cerevisiae. These fungi are responsible for causing rottening of the fruits, deterioration of quality of grains and gross loss of productivity. 
Isolate 1: The colonies were initially flat and dirty white and turned black at maturity due to formation of black conidia. The hyphae were septate and branched. Conidiophores were club shaped with globose head, aseptate branched and erect. The conidiophores arose from a foot cell and terminated in a vesicle that give rise to chains of two or more spores suspended on the sterigma. The spores were oval and dark. This isolate was identified as Aspergillus niger.

Isolate 2: The colonies were white and fluffy in appearance. Mycelia were interwoven and rhizoids were hair like. The hyphae were branched and coenocytic. Sporangiophores were brown, erect and aseptate. The sporangia were blackish brown. Spores were oval in shape. The isolate was identified as Rhizopus stolonifer.

Isolate 3: this fungus initially showed granular white colonies and turned yellowish green with maturity due to production of conidia. Hyphae were branched and septate. The conidiophores were erect, aseptate, profusely branched with sterigmata on the globular vesicle on which the conidia were present. The conidia were greenish, globose to subglobose in shape with rough surface and occur in chains of two or more. The isolate was identified as Aspergillus flavus.

Isolate 4: This fungus showed grey colony with ring of visible sclerotia (brown balls). The conidiophores were highly branched. The isolate was identified as Botrytis cinerea.

Isolate 5: This fungus developed conidiophores and conidia which were light brown in color. The conidia were muriform in shape. Conidia showed vertical and transverse septa and were organized in branched chains. The isolate was identified as Alternaria alternata.

Isolate 6: This fungus showed branched mycelium with finger like haustoria, aseptate and irregularly branched hyphae. Sporangium was thin walled and light yellow coloured. The isolate was identified as Phytophthora infestans.

Isolate 7: This fungus showed Grey-white dusty fungal growth consisting of mycelia, conidia and conidiophores. Cleistothecium was spherical, initially white and turns to yellowish-brown to black in color. The isolate was identified as Uncinula necator.

Isolate 8: This fungus showed brown, cylindrical to ellipsoidal conidia. Appresoria dark brown and irregularly lobed. The isolate was identified as Colletotricum musae.

Isolate 9: This fungus showed white mycelia initially and later became purple in color. It showed conidiophores in aggregates with flask shape projections. Macroconidia showed septation and pointed at the ends. Microconidia are non septate. The isolate was identified as Fusarium oxysporum.

Isolate 10: This fungus showed brown to black, globose to pyriform ostiolate pycnidia. Two types of conidia are produced within a pycnidium. One type of conidium is hyaline, thin walled and unicellular and the other one is thick walled and bicelled with four to six longitudinal striations. The isolate was identified as Diplodia natalensis.

Isolate 11: This fungus showed brown to dark reddish brown, opaque spores. Spores showed globose to sub globose shape. Spores with ridges. The isolate was identified as Tilletia indica.

Isolate 12: This fungus is unicellular and showed egg shape and sometime spherical shape of cells. Budding is seen. The cell structure consists of nucleus, oil droplets, glycogen and chromatin substances. The isolate was identified as Saccharomyces cerevisae.

Table 1: list of infected plants and its parts and causal fungi

\begin{tabular}{|l|l|l|l|}
\hline $\begin{array}{l}\text { Sr. } \\
\text { No. }\end{array}$ & Infected plants & Infected part & Causal organisms \\
\hline 1 & Fragaria sps. & Garden Strawberry & Botrytis cinerea \\
\hline 2 & Punica granatum & Pomegranate fruit & Alternaria alternate; Aspergillus niger \\
\hline 3 & Vitis vinifera & Grapes & Uncinula necator \\
\hline 4 & Musa acuminata & Banana fruit & Colletotricum musae \\
\hline 5 & Malus domestica & Apple fruit & Botrytis cinerea; Colletotricum musae \\
\hline 6 & Citrullus lanatus & Watermelon & Fusarium oxysporum \\
\hline 7 & Carica papaya & Papaya fruit & $\begin{array}{l}\text { Aspergillus niger; Aspergillus flavus } \\
\text { Rhizopus stolonifer }\end{array}$ \\
\hline 8 & Beta vulgaris & Beet root & Fusarium oxysporum \\
\hline 9 & Annona squamosa & Custard apple & Diplodia natalensis \\
\hline 10 & Triticum aestivum & Wheat grains & Tilletia indica \\
\hline 11 & Solanum tuberosum & Potato tubers & Phytophthora infestans \\
\hline 12 & Sorghum Bicolor & Sorghum grains & Fusarium oxysporum; niger \\
\hline 13 & Solanum lycopersicum & Tomato fruit & Aspergillus niger; Alternaria alternata; Rhizopus stolonifer \\
\hline 14 & Allium cepa & Onion bulb & $\begin{array}{l}\text { Aspergillus niger; } \\
\text { Fusarium oxysporum; } \text { S. cerevisiae }\end{array}$ \\
\hline
\end{tabular}




\section{References}

Barnnet HL, Hunter BB (1972). Illustrated genera of imperfect Fungi- APS press, Minnesota.

Downes F. P. and Ito K., (Eds.), 2001, Compendium of Methods for the Microbiological Examination of Foods, 4th Ed., APHA, Washington, D.C.
Franzier WC,Westhoff DC (1991). Food Microbiology (3rd ed.) Tata Mc GrawHill publishing Company Ltd. New Delhi pp 17-21.

Lloyd BB (1993). Fungi in food. An Overview In: Encyclopeadia of Food Science, Food Technology and Nutrition. Academic Press Ltd. London pp. 4327-4337. 